\title{
INOVASI PENDIDIKAN ISLAM MASA PANDEMI COVID 19 DI MA AL URWATUL WUTSQO JOMBANG
}

\author{
Ali Mustofa \\ Prodi Pendidikan Agama Islam, STIT Al Urwatul Wutsqo Jombang \\ e-mail: aljep_90@yahoo.com
}

\begin{abstract}
Pandemic of Coronavirus Disease (Covid-19) in Indonesia has changed all education models, including in Jombang. Many problems changes for school education. Such as teachers are facing hard challenges. Educators are required to be creative in delivering material through online learning media. It also needs to be invincible with the level of educational needs. MA Al Urwatul Wutsqo Jombang makes effort to deliver Islamic education even in pandemic conditions. This is done through online and offline. The online or distance learning has been carried out in several ways, namely the delivery of materials and assignments through the elearning program, email, What Sapp and using virtual face through zoom meeting application. Meanwhile the offline is done by taking an assignment in the morning at school and collected on the following day, then next is limited meeting that is reducing face-toface hours, and designing classes based on the health protocols.
\end{abstract}

Key words: Islamic educational innovation, pandemic, Covid-19

\section{PENDAHULUAN}

Semenjak pandemi Covid-19 di Indonesia, menyebabkan dampak yang problematik di segala bidang. Termasuk bidang pendidikan. Banyak persoalan dialami para praktisi pendidikan di sekolah. Guru menghadapi tantangan berat dengan adanya pandemi Covid-19 ini. Pendidik dituntut kreatif dalam penyampaian materi melalui media pembelajaran daring. Ini perlu disesuaikan juga dengan jenjang pendidikan dalam kebutuhannya. Dampaknya akan menimbulkan tekanan fisik maupun psikis (mental). Tuntutan untuk kreatif dalam mengantisipasi berhentinya proses pembelajaran tatap muka di kelas. Hal ini tentu tidak mudah. Surat Edaran Nomor 4 Tahun 2020 tentang Pelaksanaan Kebijakan Pendidikan dalam Masa Darurat Penyebaran Corona Virus Disease (Covid-19) yang diterbitkan oleh Menteri Pendidikan dan Kebudayaan Republik Indonesia. Surat edaran tersebut menekankan bahwa proses pembelajaran dilakukan dengan menggunakan media daring (online). Artinya, proses belajar mengajar bagi peserta didik untuk sementara waktu dilakukan 
di rumah. Sekalipun demikian, peran guru sebagai pendidik tetap dilaksanakan dengan memanfaatkan media pembelajaran yang ada.

Satuan pendidikan yang berada di daerah zona kuning, oranye, dan merah, dilarang melakukan proses pembelajaran tatap muka di satuan pendidikan dan tetap melanjutkan belajar dari rumah (BDR $)^{1}$. Hal ini menjadikan kesulitan tersendiri bagi para pendidik, lebih-lebih guru pendidikan Islam. Oleh karena itu untuk menyikapi hal tersebut MA Al-Urwatul Wutsqo Jombang menerapkan inovasi pendidikan Islam tersendiri pada masa pandemi covid 19.

\section{PEMBAHASAN}

\section{A. Inovasi Pendidikan Islam}

Proses belajar mengajar harus didasarkan pada prinsip belajar siswa aktif (Student active learning). Lebih menekankan pada proses pembelajaran dan bukan mengajar. Proses pembelajaran di dasarkan pada learning kompetensi yaitu peserta didik akan memiliki pengetahuan, ketrampilan, sikap, wawasan dan penerapannya sesuai dengan kriteria atau tujuan pembelajaran. Proses beelajar diorientasikan pada pengembangan kepribadian yang optimal dan didasarkan pada nilai-nilai ilahiyah. Menurut prinsip ini, peserta didik diberi kesempatan untuk secara aktif merealisaikan segala potensi bawaan kearah tujuan yang diinginkan yaitu menjdi manusia muslim yang berkualitas ${ }^{2}$

1. Inovasi Media

a. Media dalam Pembelajaran Pendidikan Islam

Proses pembelajaran adalah proses komunikasi antara guru dan siswa melalui bahasa verbal sebagai media utama penyampaian materi pembelajaran. Dalam kondisi semacam ini, proses pembelajaran sangat tergantung kepada guru sebagai sumber belajar.

Namun demikian, pada kenyataannya tidak semua bahan pelajaran dapat disajikan oleh guru secara langsung. Untuk mempelajari bagaimana

\footnotetext{
1 Keputusan Bersama 4 Menteri; Menteri Pendidikan dan Kebudayaan, Menteri Agama, Menteri Kesehatan, dan Menteri Dalam Negeri, Panduan Penyelenggaraan Pembelajaran Pada Tahun Ajaran 2020/2021 dan Tahun Akademik 2020/2021 di Masa Pandemi, (2020), 7.

${ }^{2}$ Hujair AH. Sanaky. Paradigma Pendidikan Islami. (Jakarta: Satria insani Press. 2003), 191
} 
kehidupan makhluk hidup di dasar laut, tidak mungkin guru membimbing siswa langsung menyelam ke dasar lautan, atau membelah dada manusia hanya untuk mempelajari cara kerja organ tubuh manusia. Akan tetapi guru dapat menggunakan berbagai macam alat bantu dalam menyampaikan pengejaran. Alat bantu belajar inilah yang dimaksud dengan media atau alat peraga pembelajaran. ${ }^{3}$

Terkait dengan pembelajaran Pendidikan Islam, maka media yang digunakan juga bermacam-macam. Usaha Nabi dalam menanamkan aqidah agama yang dibawanya dapat diterima dengan mudah oleh umatnya tidak lain dengan menggunakan media yang tepat berupa media contoh/teladan perbuatan-perbuatan baik Nabi sendiri (Uswatun Khasanab). Istilah "Uswatun Khasanab" dalam dunia pendidikan dapat diidentifikasikan dengan istilah “demonstrasi” yaitu memberikan contoh dan menunjukkan tentang cara berbuat atau melakukan sesuatu. Media ini selalu digunakan Nabi dalam mengajarkan ajaran-ajaran agama kepada umatnya, misalnya dalam mempraktekkan sholat dan lain-lain.

Selanjutnya, melalui suri tauladan atau model perbuatan dan tindakan yang baik, maka guru agama akan dapat menumbuh-kembangkan sifat dan sikap yang baik pula terhadap anak didik.

Oleh sebab itu, media pendidikan Islam dapat diartikan semua aktifitas yang ada hubungannya dengan materi pendidikan agama Islam, baik yang berupa alat yang dapat diperagakan maupun teknik/metode yang secara efektif dapat digunakan oleh guru agama dalam rangka mencapai tujuan tertentu dan tidak bertentangan dengan ajaran Islam. ${ }^{4}$

b. Macam-macam Media dalam Pembelajaran Pendidikan Islam

Media pembelajaran pendidikan Islam merupakan wadah dari pesan yang disampaikan oleh sumber atau penyalurnya yaitu pendidik, kepada sasaran atau penerima pesan, yakni peserta didik yang belajar pendidikan agama Islam. ${ }^{5}$ Tujuan penggunaan media pembelajaran

\footnotetext{
${ }^{3}$ Wina Sanjaya, Perencanaan dan Desain Sistem Pembelajaran (Jakarta: Kencana, 2011), 199.

${ }^{4}$ Ramayulis, Ilmu Pendidikan Islam (Jakarta : Kalam Mulia, 2002), 107.

${ }^{5}$ Azhar Arsyad, Media Pembelajaran (Jakarta: Raja Grafindo Persada, 1997), 199.
} 
pendidikan agama Islam tersebut adalah supaya proses pembelajaran pendidikan agama Islam dapat berlangsung dengan baik. Dari jenisnya, media pembelajaran pendidikan agama Islam dapat diklasifikasikan menjadi dua jenis, yakni media yang bersifat materi (benda) dan media yang bersifat non materi (bukan benda).

1) Media yang Bersifat Materi

Media pembelajaran yang bersifat materi ialah media yang berupa benda mati yang dapat mendukung proses kegiatan belajar-mengajar yang disebut juga dengan media peraga, seperti ruang kelas, perlengkapan belajar, dan lain sebagainya. Media ini mempunyai cakupan yang sangat luas, di antaranya adalah:

a) Media Audio

Media audio ialah media atau bahan yang mengandung pesan dalam bentuk auditif (pita suara atau piringan suara) yang dapat merangsang pikiran dan perasaan pendengar sehingga terjadi proses belajar. Media audio berkaitan dengan indra pendengar, dimana pesan yang disampaikan dituangkan dalam lambang-lambang auditif, baik verbal ( kedalam kata-kata atau bahasa lisan) maupun non verbal.

Hubungan media audio ini dengan tujuan pembelajaran pendidikan agama Islam sangat erat. Dari sisi kognitif media audio ini dapat dipergunakan untuk mengajarkan berbagai aturan dan prinsip. Dari segi afektif media audio ini dapat menciptakan suasana pembelajaran dan segi psikomotor, media audio ini untuk mengajarkan media ketrampilan verbal. Sebagai media yang bersifat auditif, maka media ini berhubungan erat dengan radio, alat perekam pita magnetik, piringan hitam, atau mungkin laboratorium bahasa ${ }^{6}$

b) Media $\operatorname{Cetak}^{7}$

Macam-macam media cetak diantaranya: gambar/foto, diagram, bagan, poster, grafik, buku. ${ }^{8}$

\footnotetext{
${ }^{6}$ Asnawir dan Basyiruddin Usman, Media Pembelajaran (Jakarta: Ciputat Pers. 2002 ), 101.

${ }^{7}$ Mukhtar, Desain Pembelajaran Pendidikan Agama Islam (Jakarta: Misaka Galiza, 2003), 105.

${ }^{8}$ Wina Sanjaya, Perencanaan, 214-215.
} 
c)Media Elektronik

Media ini diciptakan untuk menyampaikan informasi pendidikan yang dapat dimanfaatkan secara umum, baik di kalangan pendidikan maupun masyarakat secara luas. Beberapa media elektronik yang di maksud antara lain: slide dan film strip, film, televise, radio ${ }^{9}$ dan komputer $^{10}$

2) Media yang Bersifat Non-Materi

Media pendidikan yang bersifat non materi memiliki sifat yang abstrak dan hanya dapat diwujudkan melalui perbuatan dan tingkah laku seorang pendidik terhadap anak didiknya. Diantara media yang termasuk dalam kategori ini adalah: keteladanan, perintah, tingkah laku, ganjaran dan hukuman. ${ }^{11}$

2. Prinsip-prinsip Penggunaan Media dalam Pembelajaran PAI

Apabila umat Islam mau mempelajari pelaksanaan pendidikan Islam sejak zaman silam sampai sekarang, tentunya para pendidik itu telah mempergunakan media pendidikan Islam yang bermacam-macam, walaupun diakui media yang digunakan ada kekurangannya. Oleh karena itu, media pendidikan ini harus searah dengan Al-Qur'an dan as-sunnah, tidak boleh bertentangan dengan Al-Qur'an dan as-sunnah. Prinsip-prinsip yang dapat dijadikan dasar dalam pengembangan atau penggalian kesejahteraan manusia di dunia yaitu: ${ }^{12}$

Dalam menyelenggarakan kegiatan untuk kesejahteraan hidup manusia, yang termasuk didalamnya penyelenggaraan media pendidikan Islam harus mendasarkan kepada dua prinsip, yaitu: 1) Memudahkan dan tidak mempersulit, 2) Menggembirakan dan tidak menyusahkan.

3. Aplikasi Media dalam Pembelajaran PAI

Sebelum pendidik mengajarkan pokok bahasan pembelajaran terlebih dahulu harus menyiapkan dan memperhitungkan alat bantu/media apa saja

\footnotetext{
${ }^{9}$ Abuddin Nata, Perspektif Islam tentang Strategi Pembelajaran (Jakarta: Kencana, 2009), Hlm, 299-300.

${ }^{10}$ Sudjarwo S, Teknologi Pendidikan (Jakarta: Erlangga, 1988), 76.

${ }^{11}$ Abuddin Nata, Perspektif, 286.

12 Abuddin Nata, Perspektif, 238.
} 
yang dapat dipakai dari berbagai kegiatan pembelajaran yang mungkin dilakukannya sesuai dengan mata pelajaran yang akan diajarkan. Dalam menerapkan media pembelajaran pendidikan agama Islam harus dilakukan cara yang tepat dan praktis yang sesuai dengan kebutuhan peserta didik, sehingga dalam proses belajar mengajar dapat berjalan dengan efektif dan efisien. Selain hal tersebut pemilihan metode mengajar yang sesuai dengan media pembelajaran juga sangat penting karena akan berdampak pada tercapainya tujuan pembelajaran.

Media pembelajaran yang diterapkan oleh guru pendidikan agama Islam harus sesuai dengan kebutuhan peserta didik. Demikian juga halnya dengan penyesuaian antara media pembelajaran yang dipakai dengan kebutuhan peserta didik yang banyak dan bermacam-macam, namun secara garis besarnya pemilihan media pembelajaran tersebut harus sesuai dengan kebutuhan kebanyakan peserta didik.

Berikut adalah penerapan media pembelajaran melalui bahan bacaan atau bahan cetak, alat-alat audio visual (AVA), contoh-contoh kelakuan dan melalui media masyarakat dan alam sekitar. ${ }^{13}$

\section{B. Konsep Pendidikan Islam}

\section{Pengertian Pendidikan Islam.}

Istilah pendidikan dalam konteks Islam pada umumnya mengacu kepada term al-tarbiyah, al-ta'lim dan al-ta'dib. Dari ketiga istilah tersebut term yang populer digunakan dalam praktek pendidikan Islam adalah term altarbiyah. Sedangkan term al-ta'dib dan al-ta'lim jarang digunakan. ${ }^{14}$ Sedangkan menurut istilah menurut Abuddin Nata, berdasarkan ringkasan dari berbagai pendapat ahli pendidikan Islam adalah pendidikan yang seluruh komponen atau aspeknya didasarkan pada ajaran Islam. Visi, misi, tujuan, proses belajar mengajar, pendidik, peserta didik, hubungan pendidik dan peserta didik, kurikulum, bahan ajar, sarana prasarana, pengelolaan, lingkungan dan aspek

${ }^{13}$ Chabib Thoha, dkk., Metodologi Pembelajaran Agama (Yogyakarta: Pustaka Pelajar, 1999), 133 - 134

${ }^{14}$ Abdul Halim , Filsafat Pendidikan Islam: Pendekatan Historis, Teoris dan Praktis (Jakarta: Ciputat Pers, 2002), 25 . 
atau komponen pendidikan lainnya yang didasarkan pada ajaran Islam. ${ }^{15}$ Pendidikan Islam paling tidak menyangkut keimanan, sikap dan keterampilan serta sesuai dengan perkembangan zaman. ${ }^{16}$

Syari'at Islam tidak akan dihayati dan diamalkan orang kalau hanya diajarkan saja, tetapi harus dididik melalui proses pendidikan. Nabi telah mengajak orang untuk beriman dan beramal serta berakhlak baik sesuai ajaran Islam dengan berbagai metode dan pendekatan. Ajaran Islam lebih banyak ditujukan kepada perbaikan sikap mental yang akan terwujud dalam amal perbuatan, ajaran Islam tidak memisahkan antara iman dan amal saleh. Oleh karena itu pendidikan Islam adalah sekaligus pendidikan iman dan pendidikan amal. ${ }^{17}$ Dengan demikian secara umum dapat disimpulkan bahwa pendidikan Islam adalah pembentukan kepribadian muslim.

\section{Dasar Utama Pendidikan Islam}

Dasar pendidikan Islam tertumpu dalam al Qur'an dan sunnah Nabi. Diatas dua pilar inilah dibangun konsep dasar pendidikan Islam. Titik tolaknya dimulai dari konsep manusia menurut Islam. ${ }^{18}$ Oleh karena itu pendidikan Islam sebagai suatu usaha membentuk manusia, harus mempunyai dasar kemana semua kegiatan dan tujuan pendidikan Islam itu dihubungkan. Dasar tersebut adalah al Qur'an dan sunnah Nabi yang dikembangkan dengan ijtihad (al maslahah al mursalah, istihsan, qiyas, ijma' dan lain sebagainya). Artinya rujukan pendidikan Islam diawali dari sumber pertama (al Qur'an) untuk kemudian dilanjutkan pada sumber-sumber berikutnya secara berurutan.

\section{Visi Pendidikan Islam}

Kata visi berasal dari bahasa Inggris vision, yang mengandung arti penglihatan atau daya lihat, pandangan, impian atau bayangan. Berdasarkan pengertian tersebut visi berkaitan denga teori, konsep, gagasan, pemikiran, pandangan kedepan, pertimbangan dan pandangan yang dihasilkan melalui kerja keras akal pikiran. Visi adalah konsep atau rumusan yang dihasilkan

15 Abuddin Nata, Ilmu Pendidikan Islam (Jakarta: Kencana, 2016), 30.

${ }^{16}$ Mahmud Ainul Yaqin dkk, Filsafat Pendidikan Islam (Surabaya: Kopertais IV Press, 2015), 217.

17 Zakiah Darajat, Ilmu Pendidikan Islam (Jakarta: PT.Bumi Aksara, 2014), 28.

${ }^{18}$ Epi Partikasari, http://www.academia.edu/3759908/Makalah Konsep Pendidikan Islam diakses tanggal 08 Januari 2017. 
melalui pemikiran. ${ }^{19}$ Berdasarkan pada pengertian kebahasaan tersebut, maka secara terminologi, visi yaitu tujuan jangka panjang, cita-cita masa depan, keinginan besar yang hendak dicapai, angan-angan dan impian ideal tentang sesuatu yang hendak di wujudkan.

Pengertian tentang visi jika dihubungkan dengan pendidikan Islam, maka visi pendidikan Islam dapat diartikan sebagai tujuan jangka panjang, citacita masa depan dan impian ideal yang ingin diwujudkan oleh pendidikan Islam. Visi pendidikan Islam sesungguhnya melekat pada cita-cita dan tujuan jangka panjang ajaran Islam itu sendiri, yaitu mewujudkan rahmat bagi seluruh umat manusia, sesuai dengan firman Allah SW'T dalam Q.S al-Anbiya' (21): 107:

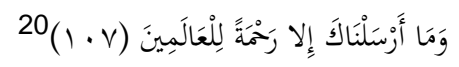

Artinya: "Dan Tiadalah Kami mengutus kamu, melainkan untuk (menjadi) rabmat bagi semesta alam.” (Q.S.al-Anbiya' (21): 107.) ${ }^{21}$

Ayat tersebut oleh Imam al-Maraghiy ditafsirkan, sebagai berikut:

"Bahwa maksud dari ayat yang artinya tidaklah Aku utus engkau Muhammad melainkan agar menjadi rahmat bagi seluruh alam, adalah bahwa tidaklah Aku utus engkau Muhammad dengan al Qur'an ini, serta berbagai perumpamaan dari ajaran agama dan hukum yang menjadi dasar rujukan untuk mencapai bahagia dunia dan akhirat, melainkan agar menjadi rahmat dan petunjuk bagi mereka dalamm segala urusan kehidupan dunia dan akhiratnya,"

Visi pendidikan Islam dengan demikian dapat dirumuskan sebagai berikut:

"Menjadikan pendidikan Islam sebagai pranata yang kuat, berwibawa, efektif, dan kredibel dalam mewujudkan cita-cita ajaran Islam."22

Pendidikan Islam berdasarkan visi tersebut harus diarahkan kepada tercapainya visi tersebut serta menciptakan generasi yang cerdas dan faham tentang al Qur'an disamping materi-materi umum.

${ }^{19}$ Nata, Ilmu Pendidikan, 35.

20 Al-Qur'an Surat al-Anbiya' (21): 107.

${ }^{21}$ Kementerian Agama RI, al Qur'an Tajwid dan Terjemah (Bandung: Sygma Examedia Arkanleema, 2010), 331.

22 Nata, Imu Pendidikan, 38. 


\title{
4. Misi Pendidikan Islam
}

Misi berasal dari bahasa Inggris, mission yang memiliki arti tugas, perutusan, utusan, atau misi. Dari pengertian kebahasaan tersebut, maka mission dapat diartikan sebagai tugas-tugas atau pekerjaan yang harus dilaksanakan dalam rangka mencapai visi yang ditetapkan. Dengan demikian, antara visi dan misi harus memiliki hubungan fungsional- simbiotik, yakni saling mengisi dan timbal balik. ${ }^{23}$

Visi dan misi harus memiliki keterkaitan atau hubungan agar dapat berjalan sesuai harapan, dari satu sisi visi mendasari rumusan misi, sedangkan dari sisi lain, keberadaan misi akan menjadi sebab tercapainya visi. Karena pekerjaan merupakan kegiatan, maka misi harus berisi berbagai kegiatan yang mengarah kepada tercapainya visi. Visi dan misi pendidikan Islam lebih lengkap dibandingkan dengan visi dan misi pendidikan Barat. Visi dan misi pendidikan Barat hanya menekankan salah satu aspek dari kehidupan manusia, yakni aspek rasio dan fisik. Adapun visi dan misi pendidikan Islam selain menekankan rasio dan fisik, juga spiritual, moral, dan sosial sehingga tercapai kehidupan manusia yang seutuhnya. Visi dan misi pendidikan Islam bersumber pada visi dan misi ajaran Islam, karena hakikat pendidikan Islam adalah memasyarakatkan ajaran Islam agar dipahami, dihayati dan diamalkan oleh umat manusia, sehingga tercapai kebahagiaan hidup secara seimbang dunia dan akhirat.

\begin{abstract}
ANALISIS
Pendidikan Islam dalam era globalisasi ini menghadapi tantangan terutama moral sosial yaitu kegiatan penataan kehidupan yang paling baik yang seharusnya dialami oleh generasi muda agar mampu menghadapi masa depan dengan integritas (kesatuan) yang tangguh. Untuk itu maka Pendidikan Islam diharapkan mampu menyusun polapikir yang sistematis untuk membina pribadi muslim yang kreatif dan berintegritas tinggi, sehingga mampu menyesuaikan diri dengan perubahan yang terjadi di masyarakat. Oleh karena itu inovasi pembelajaran Pendidikan Islam harus dilakukan.
\end{abstract}

${ }^{23}$ Nata, Imu Pendidikan, 39. 
Pendidikan sebagai faktor kunci dalam pembangunan bangsa dan Negara. Dua masalah pokok yang dihadapi adalah peningkatan mutu dan perluasaan kesempatan belajar. Dan pendayagunaan teknologi pendidikan (Education Technology) atau apa pun istilah yang digunakan: teknologi untuk pendidikan (Technology for Education), teknologi informasi (Information Technology/IT), atau teknologi komunikasi dan informasi (Information and Communication Technology/ICT) diyakini sebagai salah satu cara strategis mengatasi masalah tersebut. ${ }^{24}$

Inovasi pembelajaran pendidikan agama Islam sangat perlu dilakukan. Salah satunya adalah pembelajaran berbasis ICT sebagai alternatif baru dalam proses pembelajaran PAI sehingga problematika dapat dipecahkan serta tujuan yang diinginkan dapat terealisasikan. Namun bentuk penerapan dari pendidikan agama Islam berbasis ICT inilah yang akan dikaji serta didesain sesuai kebutuhan peserta didik.

Sebagaimana diungkapkan oleh Tajul Ariffin Noordin bahwa penggunaan teknologi canggih seperti komputer sangat penting dan dapat mempengaruhi perkembangan PAI dalam lima tahap. Pertama, penggunaan komputer dalam pembelajaran dapat berperan sebagai alat bantu untuk memungkinkan PAI meluaskan paradigma ilmunya. Kedua penggunaan teknologi canggih dapat digunakan untuk mewujudkan integrasi antara PAI dengan pendidikan sains. Ketiga, bagaimana kita dapat menggunakan dan mengeksploitasi secara positif segala bentuk teknologi yang ada untuk menjadikan PAI sebagai dasar pengajian ilmu pendidikan atau dasar ilmuilmu. Keempat, untuk mewujudkan suatu rangkaian PAI sedunia. Kemudahan teknologi dapat digunakan untuk merangka dan membina satu paradigma dan kurikulum PAI yang sama untuk negara-negara Islam; kelima untuk membina konsep ketauhidan ilmuilmu. Ini bermaksud dengan teknologi kita dapat menerangkan bahwa ilmu itu sebenarnya bersifat kesatuan. Tahap kelima ini melengkapkan usaha kita untuk membina peradaban Islam yang maju. Kelima pengaruh teknologi terhadap perkembangan pembelajaran PAI tersebut dapat dibuktikan dan dirasakan hasil

24 Arbain Nurdin, Inovasi Pembelajaran Pendidikan Agama Islam Di Era Information And Communication Technology, Tadrîs Volume 11 Nomor 1 Juni 2016, 49 
positifnya bila teknologi informasi di zaman globalisasi saat ini benar-benar dimanfaatkan serta didayagunakan oleh stakeholders pendidikan khususnya guru PAI. ${ }^{25}$

Pandemi Covid-19 di Indonesia merubah model pendidikan MA Al Urwatul Wutsqo Jombang. Lembaga tersebut terus berupaya untuk bisa menyampaikan pendidikan Islam walaupun dalam kondisi pandemi. Inovasi pembelajaran pendidikan Islam di masa pandemi yakni, daring dan luring.

Pertama, daring atau dalam jaringan (pembelajaran jarak jauh) dilakukan melalui beberapa cara, yaitu penyampaian materi dan penugasan melalui program e-learning madrasah, email, whatsapp (penjelasan lewat media vidio pembelajaran, media PPT materi dll) dan mengunakan tatap muka virtual melalui aplikasi zoom meetings. Ini merupakan inovasi yang mengunakan media pembelajaran yang bersifat materi ialah media yang berupa benda mati yang dapat mendukung proses kegiatan belajar-mengajar yang disebut juga dengan media peraga, seperti ruang kelas, perlengkapan belajar, dan lain sebagainya. Media ini mempunyai cakupan yang sangat luas, di antaranya adalah: media audio, cetak dan elektronik

Kedua, yaitu dengan luring, bentuk yang dilakukan adalah dengan penugasan yang diambil di pagi hari disekolah dan dikumpulkan pada hari berikutnya, kemudian pertmeuan terbatas yaitu mengurangi jam tatap muka, dan mendesain kelas yang sesuai protokol kesehatan. Model kedua ini mengunakan sistem protokol yang sangat ketat, mengingat bahwa mudahnya Covid-19 menular pada yang lain. Sehingga setiap sebelum masuk kelas dilakukan pengecekan suhu tubuh, cuci tangan, bermasker dan jaga jarak, antar siswa dan guru.

\section{KESIMPULAN}

Pandemi Covid-19 di Indonesia merubah semua model pendidikan di Indonesia, termasuk di wilayah Jombang. MA Al Urwatul Wutsqo Jombang terus berupaya untuk bisa menyampaikan pendidikan Islam walaupun dalam kondisi pandemi. Inovasi pembelajaran pendidikan Islam di masa pandemi yakni, daring dan luring. Pertama, daring atau dalam jaringan (pembelajaran jarak jauh) dilakukan melalui beberapa cara, yaitu penyampaian materi dan penugasan melalui program e-learning madrasah, email,

25 Arbain Nurdin, Inovasi Pembelajaran Pendidikan Agama Islam Di Era Information And Communication Technology, Tadrîs Volume 11 Nomor 1 Juni 2016, 60 
whatsapp (penjelasan lewat media vidio pembelajaran, media PPT materi dll) dan mengunakan tatap muka virtual melalui aplikasi zoom meetings. Kedua, yaitu dengan luring, bentuk yang dilakukan adalah dengan penugasan yang diambil di pagi hari disekolah dan dikumpulkan pada hari berikutnya, kemudian pertmeuan terbatas yaitu mengurangi jam tatap muka, dan mendesain kelas yang sesuai protokol kesehatan.

\section{DAFTAR PUSTAKA}

AH. Sanaky, Hujair. Paradigma Pendidikan Islami. Jakarta: Satria insani Press. 2003

Ainul Yaqin, Mahmud dkk, Filsafat Pendidikan Islam, Surabaya: Kopertais IV Press, 2015.

Arbain Nurdin, Inovasi Pembelajaran Pendidikan Agama Islam Di Era Information And Communication Technology, Tadrîs Volume 11 Nomor 1 Juni 2016.

Arsyad, Azhar, Media Pembelajaran, Jakarta: Raja Grafindo Persada, 1997.

Asnawir dan Basyiruddin Usman, Media Pembelajaran, Jakarta: Ciputat Pers. 2002 .

Darajat, Zakiah, Ilmu Pendidikan Islam, Jakarta: Bumi Aksara, 2014.

Halim, Abdul, Filsafat Pendidikan Islam: Pendekatan Historis, Teoris dan Praktis, Jakarta: Ciputat Pers, 2002.

Kementerian Agama RI, al Qur'an Tajwid dan Terjemah, Bandung: Sygma Examedia Arkanleema, 2010.

Keputusan Bersama 4 Menteri; Menteri Pendidikan dan Kebudayaan, Menteri Agama, Menteri Kesehatan, dan Menteri Dalam Negeri, Panduan Penyelenggaraan Pembelajaran Pada Tahun Ajaran 2020/2021 dan Tahun Akademik 2020/2021 di Masa Pandemi, 2020

Mukhtar, Desain Pembelajaran Pendidikan Agama Islam, Jakarta: Misaka Galiza, 2003.

Nata, Abuddin, Imu Pendidikan Islam, Jakarta: Kencana, 2016.

Nata, Abuddin, Perspektif Islam tentang Strategi Pembelajaran, Jakarta: Kencana, 2009.

Partikasari, Epi, http :// www. academia. edu/ 3759908/ Makalah _ Konsep _ Pendidikan _ Islam diakses tanggal 08 Januari 2017.

Ramayulis, Ilmu Pendidikan Islam, Jakarta : Kalam Mulia, 2002.

S, Sudjarwo, Teknologi Pendidikan, Jakarta: Erlangga, 1988. 
Sanjaya, Wina, Perencanaan dan Desain Sistem Pembelajaran, Jakarta: Kencana, 2011.

Thoha, Chabib, dkk., Metodologi Pembelajaran Agama, Yogyakarta: Pustaka Pelajar, 1999. 